Journal of Animal \& Plant Sciences, 31(5): 2021, Page: 1530-1536

ISSN (print): 1018-7081; ISSN (online): 2309-8694

https://doi.org/10.36899/JAPS.2021.5.0355

\title{
DNA BARCODING OF GASTROPOD TELESCOPIUM TELESCOPIUM (LINNAEUS, 1758) FOUND AT THE KARACHI COAST, PAKISTAN
}

\author{
N. George, G. Siddiqui, F. Muhammad and Z. George \\ Centre of Excellence in Marine Biology, University of Karachi, Karachi-75270, Pakistan. \\ Corresponding Author's Email: nazishgeorge@yahoo.com
}

\begin{abstract}
DNA barcoding is considered an effective tool for the identification of organisms on the molecular level. The present study aimed to focus on DNA barcoding of Telescopium telescopium (Gastropod) using mitochondrial cytochrome C oxidase subunit I (COI) gene and to correlate it with morphologically identified species found along the coast of Karachi, Pakistan. Our results of BLAST analyses show $95 \%$ similarity with the partial sequence of $T$. telescopium reported from Goa and Kerala, India whereas, the genomic distance of mt-COI gene among the $T$. telescopium population is $0 \%$ to 45\%. Telescopium telescopium of Karachi, Pakistan showed $0 \%$ evolutionary divergence with the T. telescopium of Goa and Kerala, India and maximum distance $45 \%$ with T. telescopium of Bangladesh. This investigation confirmed the morphological and molecular identification of T. telescopium for the first time from Karachi, Pakistan.
\end{abstract}

Key words: DNA barcoding, mt-COI gene sequence, Telescopium telescopium, Molecular phylogeny. Published first online January 29, 2021

Published final August 07, 2021.

\section{INTRODUCTION}

To understand the diversity of any region it is very important to have an accurate identification of taxon (Fontanilla et al., 2014). According to taxonomists, traditional taxonomic characteristics are usually not enough for the accurate identification of species (Packer et al., 2009), especially in the case of morphologically similar species and when samples are collected from juvenile life stages of organisms (Gossner and Hausmann, 2009). Traditional taxonomy in addition to molecular techniques is proved to be an authentic method especially DNA barcoding is the best-adopted method for the identification of species (Hebert et al., 2003a; Hebert et al., 2003b; Ferri et al., 2009). Mitochondrial cytochrome $\mathrm{C}$ oxidase subunit, I (COI) serve as standard barcode for most of the animals (Hebert et al., 2003b) in animal Kingdom and it is extensively used as a marker for phylogeographic studies and population genetics (Avise, 1994).

Gastropoda is the most diverse class of phylum Mollusca characterized by a complex variety of species exhibiting taxonomic problems in identification (Layton et al., 2014). Taxonomic confirmation of marine organisms has been done effectively by DNA barcoding. Morphometric characteristics and DNA sequencing help to analyze the phylogeny of molluscs, especially gastropods were studied comprehensively (Barco et al., 2016). DNA barcoding gives significant benefits to different fields i.e. biodiversity conservation (Kress et al., 2015), ecological monitoring (Satheesh kumar et al., 2010) and border biosecurity (Collins et al., 2012). For this purpose, marine gastropods required a library of
DNA barcodes for strong molecular identification where they match distinctly specimens to diagnostic barcode sequences (Borges et al., 2016).

The single living species of genus Telescopium of subclass caenogastropoda is surface dweller found in mudflats (Lasiak and dye, 1986; Satheesh kumar et al., 2012; Willian, 2013) and mangroves (Shamugan and Raja Gopal, 2006) and feeds on detritus (Alexander et al., 1979; Lasiak and Dye, 1986; Das et al.,1988; Houbrick,1991; Rakshit et al.,1997 and Meziane and Tsuchiya, 2002). It is abundantly found in the Indian Ocean, West and Central Indo-Pacific regions. The advanced research will help to understand the evolutionary relationship of this species with the other members of their family Potamididae and ecological association with their mangrove's ecosystem (Reid et al., 2008; Yap et al., 2009). Molecular taxonomy is the wellorganized method to find the phylogenetic relationships and identification of organisms at species-level through the DNA sequencing of mt-COI gene (Feng et al., 2011).

The present study investigated the molecular phylogeny of $T$. telescopium using mitochondrial cytochrome $\mathrm{C}$ oxidase subunit I (COI) gene and a phylogenetic tree is constructed which helps to determine the evolutionary divergence and relationship among the same species. This is the first report on DNA barcoding of a gastropod $T$. telescopium from Pakistan using COI gene.

\section{MATERIALS AND METHODS}

Study site: The Sandspit is located in the southwest part of Karachi, at $24^{\circ} 50^{\prime} \mathrm{N}$ and $66^{\circ} 56^{\prime} \mathrm{E}$ between Hawks 
Bay and Manora Channel. Manora channel connects Sandspit backwater to the Arabian Sea. During high and low tides, the seawater enters the Sandspit backwaters through Manora Channel frequently and drain back to Arabian Sea periodically (Sultana and Mustaquim, 2003). The area of Sandspit backwaters is covered with mangrove forest which is significantly important for the richness of biodiversity. The Lyari River is a source of the domestic and industrial waste but in rainy season (July to September) it brings freshwater into backwaters. T. telescopium is the dominating species of the mangrove area (Figure 1).

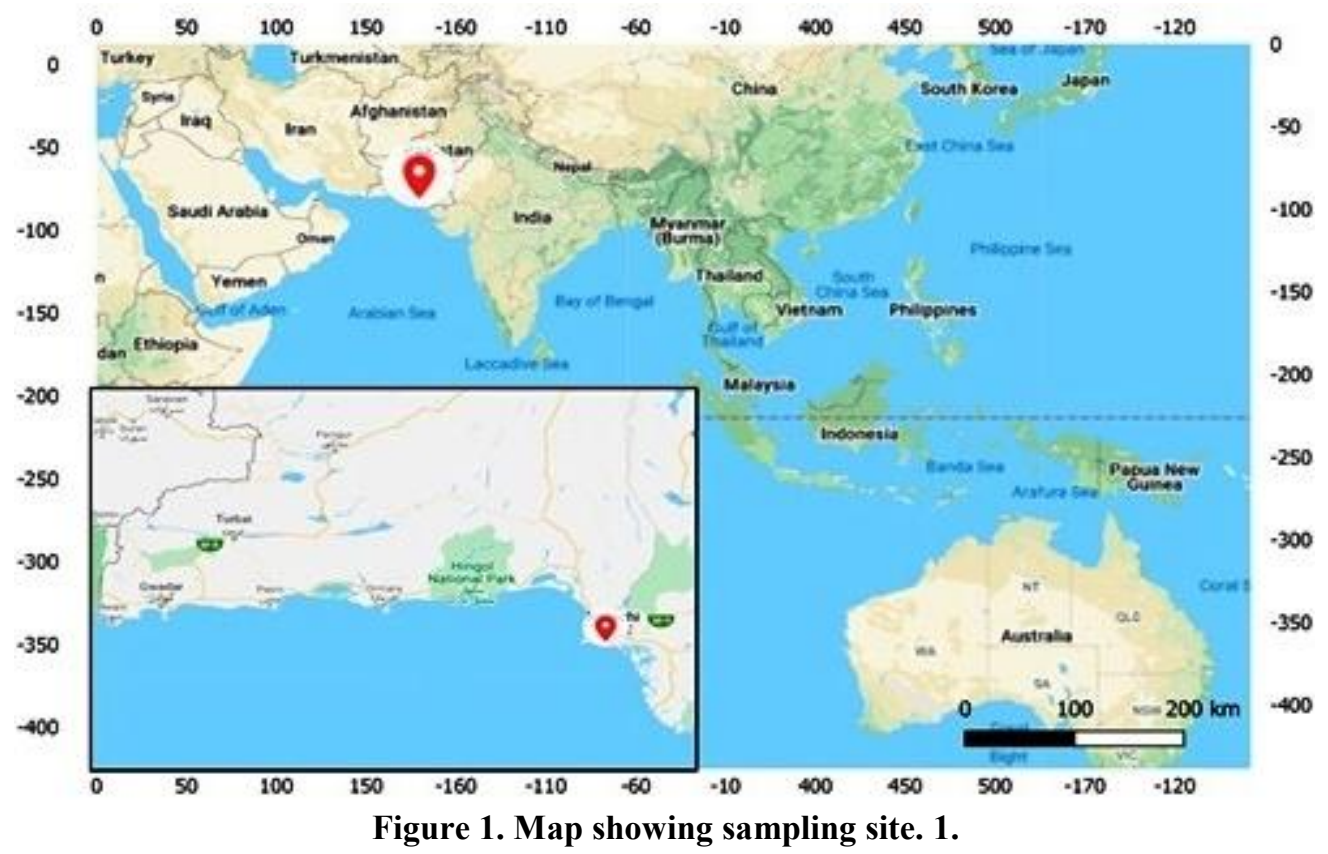

Collection of samples: $T$. telescopium were randomly collected by hand, bought to the laboratory and kept in a glass aquarium filled with seawater brought from same habitat for further study. Morphometric measurements were taken after species identification described by (Bosch et al., 1995). Shell was cracked open and its soft tissues were kept at $-20^{\circ} \mathrm{C}$ for further analyses.

DNA isolation: Total genomic DNA was extracted from muscle tissue of $T$. telescopium using Bio basic genomic DNA kit.

PCR Amplification and Gel electrophoresis: The polymerase chain reaction (PCR) amplification was performed in applied Biosystem 2720 thermal cycler, a pair of primers LCO1490: 5'GGTCAACAAATCATAAAGATATTGG-3' and LCOR2198:

5'-

TAAACTTCAGGGTGACCAAAAAATCA-3' (Folmer et al., 1994) were used for the amplification of COI gene. The PCR conditions were as: denaturation at $94{ }^{\circ} \mathrm{C}$ for 5 min; 35 cycles of $94{ }^{\circ} \mathrm{C}$ for $30 \mathrm{~s}$, annealing at $42{ }^{\circ} \mathrm{C}$ for $30 \mathrm{~s}$, and extension at $72{ }^{\circ} \mathrm{C}$ for $30 \mathrm{~s}$; and a final extension at $72{ }^{\circ} \mathrm{C}$ for $7 \mathrm{~min}$. Gel electrophoresis was run using $1.2 \%$ agarose gel with ethidium bromide (stain).

Sequencing and construction of phylogenetic tree: After successful amplification it was subsequently sequenced with the Sanger sequencing method. Softwares, including MEGA 6, and DNA Star were used for the editing and alignment of sequences. After necessary deletion and insertion, it was submitted to National Center for Biotechnology Information (NCBI) and accession number obtained (MT034052). Twelve partial sequences of $T$. telescopium from neighbor countries of the same continent (Asia) including India (JN190053.1，JN190058.1，JN190056.1，KT336817.1, AM932795.1, JX390723.1), Bangladesh (MF693397.1), Philippines (HE680642.1, HE680643.1), Thailand (HE680645.1) and from continent of Australia (HE680631.1, HE680633.1) were downloaded from gene bank in order to construct a neighbor joining phylogenetic tree using MEGA 6.

Evolutionary history of phylogenetic tree was computed and constructed by Neighbor-joining method on Kimura 2-parameter model (Kimura 1980) (Figure 3).

\section{RESULTS AND DISCUSSION}

\section{Systematics}

Class:

Subclass: Caenogastropoda

Super family: Cerithoidea (Fleming, 1822)

Family: Potamididae (Adams \& Adams, 1854) 
Genus: Telescopium

Species: T. telescopium (Linnaeus, 1758)

(WoRMS:

http://www.marinespecies.org/aphia.php?p=taxdetails\&id $=215140$ )
Morphological Characteristics: Shell 80 to $130 \mathrm{~mm}$ in length, black at first look but reddish-brown, thick, hard, moderately lustrous extended-conical, with 16 whorls, sutures poorly defined, even spiral ribs, few spiral ribs on flat base. Short siphonal canal and long snout (Figure 2).
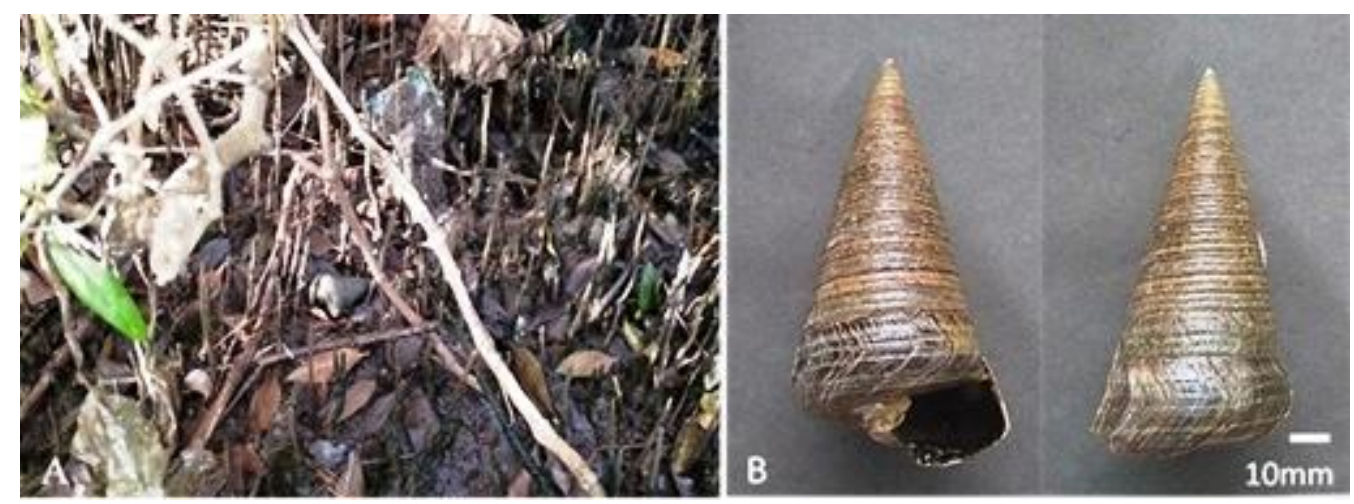

Figure 2. Photographs showing horn snail, Telescopium telescopium. A) mangrove area of Sandspit; B) Dorsal and ventral view of T. telescopium from Sandspit.

Distribution: Telescopium telescopium is found in muddy areas of the Mangrove of Indo-pacific regions. Literature shows their distribution in India, Bangladesh, Philippines, Thailand, Australia, Malaysia, Indonesia, Japan, Singapore, and Madagascar (Satheesh kumar et al., 2020).

The present study is aimed to identify horn snail, $T$. telescopium morphologically as well as phylogenetically using COI gene sequence.

Phylogenetic analysis: Phylogenetic tree of COI gene was constructed with the twelve similar sequences obtained from the NCBI and it confirms the morphological identification of T. telescopium. Previous study identified $T$. telescopium at molecular level using COI gene from Australia, Thailand, Philippines, Bangladesh and different areas of India (Table 1). T. telescopium reported from Goa and Kerala, India having accession no: AM932795.1 and JX390723.1 showed $95 \%$ similarity, while the sequence from the Bay of Bengal, India showed $85 \%$ similarity. However, the sequence from Philippines (HE680642.1, HE680643.1), and Thailand (HE680645.1) showed $84 \%$ similarity while the sequence from Bay of Bengal, India having accession \# JN190056.1 showed 83\% similarity (Figure $3)$.

The neighbor joining phylogenetic tree revealed that T. telescopium from Karachi (MT034052.1) clustered with the individuals of Goa and Kerala (AM932795.1, JX390723.1), which is reasonable understanding, only individual of Bangladesh (MF693397.1) denoted a separated clade, it may because of several complex reasons, such as pattern of current or any other physical force handicap the gene flow (Figure 3). Furthermore, it has been confirmed that among T. telescopium, there is intra-species diversification.

The geographical locations play an important role in evolutionary divergence, it might increase with increase in their geographic distance (Deza and Deza, 2013). The divergence between $T$. telescopium from Karachi, Sindh and Bangladesh is 0.45 (45\%) which lies at the peak of Bay of Bengal. Australia showed 0.16 (16\%) divergence and the samples from Philippines, Thailand and India indicated evolutionary divergence of $13 \%$ to $14 \%$. Various features, i.e. geographic barrier, geographic distance and larval behavior were reported to be responsible to bound gene flow among the different populations (Schmidt and Rand, 1999; Riginos and Nachman, 2001). Physical, climatic landscapes and biotic geography could be one of the reasons of limited gene flow even in the same continent, particularly those physical barriers produced by spatial, temporal patterns and bathymetry of oceanographic currents (Galarza et al., 2009). For example, consistent counter flow patterns and limitations among divergent water masses (Werner et al., 2007) could be a factor of great importance. Numerous other aspects may be significant, including partial dispersal ability (Waples, 1987; Duffy, 1993; Hunt, 1993; Doherty et al., 1995), limited adaptations (Koehn et al., 1980; Powers et al., 1991; Schmidt and Rand, 1999), ocean currents (Shulman and Bermingham, 1995; Benzie and Williams, 1997; Palumbi et al., 1997; RochaOlivares \& Vetter, 1999; Stepien, 1999; Snidvong and Sojisuporn, 1999), and isolation through distance (Hellberg, 1996; Lavery et al., 1996; Palumbi et al., 1997). Moreover, some Indo-Pacific taxa show increased divergence among Indian and Pacific ocean populations (Lavery et al., 1995, 1996; McMillan and Palumbi, 1995; Chenoweth et al., 1998b; Duda and Palumbi, 1999). 
Further sampling from Indian Ocean has the potential to on them globally and to reconfirm our results. reveal diversity of species and biogeographic influence

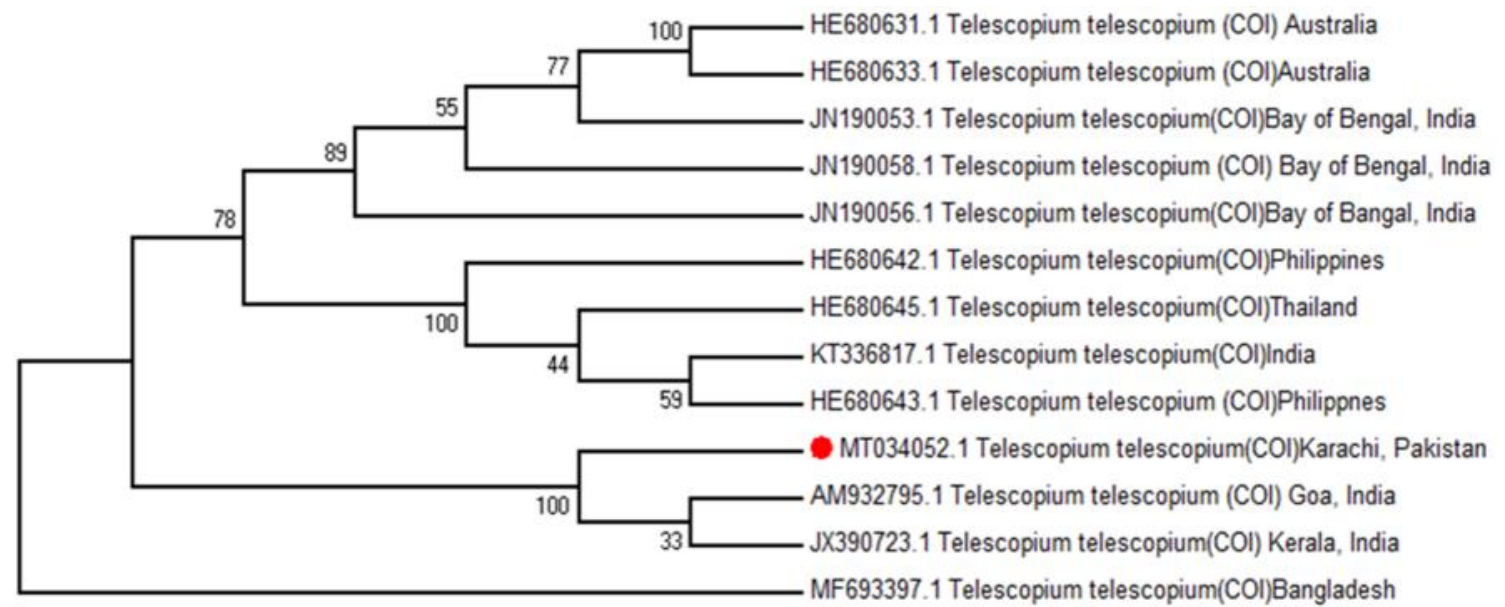

Figure 3. Neighbour- joining tree denoting the $T$. telescopium species from Karachi clustered with Goa and Kerala individuals.

Table 1. List of accession numbers used for phylogenetic analysis in study.

\begin{tabular}{clll}
\hline S. no & Taxa & Country & Accession number \\
\hline 1 & T. Telescopium & Australia & HE680631.1 \\
2 & & Australia & HE680633.1 \\
3 & Bay of Bengal, India & JN190053.1 \\
4 & Bay of Bengal, India & JN190058.1 \\
5 & Bay of Bengal, India & JN190056.1 \\
6 & India & KT336817.1 \\
7 & Philippines & HE680642.1 \\
8 & Philippines & HE680643.1 \\
9 & Thailand & HE680645.1 \\
10 & Karachi, Pakistan & MT034052.1 \\
11 & Bangladesh & AM932795.1 \\
12 & Goa, India & JX390723.1 \\
13 & Kerala, India & \\
\hline
\end{tabular}

Table 2. Evolutionary divergence of different countries between sequences of $T$. telescopium.

\begin{tabular}{|c|c|c|c|c|c|c|c|c|c|c|c|c|c|c|}
\hline S.no & & 1 & 2 & 3 & 4 & 5 & 6 & 7 & 8 & 9 & 10 & 11 & 12 & 13 \\
\hline 1 & India & - & & & & & & & & & & & & \\
\hline 2 & Karachi & 0.13 & & & & & & & & & & & & \\
\hline 3 & Philippines & 0.01 & 0.13 & & & & & & & & & & & \\
\hline 4 & Philippines & 0.01 & 0.14 & 0.01 & & & & & & & & & & \\
\hline 5 & Goa, India & 0.13 & 0.00 & 0.13 & 0.14 & & & & & & & & & \\
\hline 6 & Thailand & 0.01 & 0.13 & 0.00 & 0.01 & 0.13 & & & & & & & & \\
\hline 7 & Australia & 0.12 & 0.16 & 0.11 & 0.12 & 0.16 & 0.11 & & & & & & & \\
\hline 8 & Australia & 0.12 & 0.16 & 0.11 & 0.12 & 0.16 & 0.11 & 0.00 & & & & & & \\
\hline 9 & Bangladesh & 0.43 & 0.45 & 0.44 & 0.44 & 0.45 & 0.43 & 0.42 & 0.42 & & & & & \\
\hline 10 & India & 0.09 & 0.14 & 0.08 & 0.09 & 0.14 & 0.08 & 0.06 & 0.06 & 0.46 & & & & \\
\hline 11 & India & 0.09 & 0.13 & 0.08 & 0.09 & 0.13 & 0.08 & 0.05 & 0.05 & 0.45 & 0.06 & & & \\
\hline 12 & India & 0.09 & 0.14 & 0.09 & 0.10 & 0.14 & 0.09 & 0.03 & 0.03 & 0.43 & 0.03 & 0.02 & & \\
\hline 13 & Kerala, India & 0.13 & 0.00 & 0.13 & 0.14 & 0.00 & 0.13 & 0.16 & 0.16 & 0.45 & 0.14 & 0.13 & 0.14 & - \\
\hline
\end{tabular}


Conclusion: DNA barcoding, cytochrome oxidase I (COI) gene is proved to be a beneficial tool for the authentic identification of organisms at species level. In present study member of Family Potamididae, $T$. telescopium is analyzed morphologically as well as taxonomically and the barcoding results are assisting morphological results. These results indicate the relation between geographical locations and evolutionary divergence found between sequences of same species. The genetic distance among sequences increases with regards to increase in their geographic distance. Gene flow limitation occurs even at the same continent due to physical barriers (Ngeve et al., 2016) and geographical barriers (Riginos and Nachman 2001). These factors can differentiate individuals of same species into clades. Biogeographical partitions between lineages on the Indian Ocean waters are have been reported (Satheeshkumar et al., 2020). In future, worldwide genetic diversity studies are needed to be performed.

\section{REFERENCES}

Alexander, C.G., R. I. Cutter and D. Yellowless (1979). Studies on the composition and enzyme content of the crystalline style of Telescopium telescopium (L.) (Gastropoda). Comp. Biochem. Physiol. 64B: 83-89.

Avise, J. C (1994). Molecular Markers, Natural History and Evolution. New York: Chapman and Hall. J. Evol. Biol. 7: 761-772.

Barco, A., M. J. Raupach, S. Laakmann, H. Neumann and T. Knebelsberger (2016). Identification of North Sea molluscs with DNA barcoding. Mol. Eco. Resou. 16: 288-297.

Benzie, J.A.H and S. T. Williams (1997). Gene flow among giant clam (Tridacna maxima) populations in the west Pacific is not consistent with dispersal by present-day Ocean currents. Evolution. 51: 768-783.

Borges, L. M., C. Hollatz, J. Lobo, A. M. Cunha, A. P. Vilela and G. Calado (2016). With a little help from DNA barcoding: investigating the diversity of Gastropoda from the Portuguese coast. Scient. Rep. 6: 20226.

Bosch, D.T., S. P. Dance, R. G. Moolenbeck and P. G. Oliver (1995). Sea shells of the eastern Arabia (ed. P. dance). Motivate Publishing, Emirates printing press, Dubai, UAE. 1-296 p.

Chenoweth, S. F., J. M. Hughes, C. P. Keenan and S. Lavery (1998). When oceans meet: a teleost shows secondary intergradation at an IndianPacific interface. Proceedings of the Royal Society of London, Series B, 265: 415-420.

Collins, R.A., K. F. Armstrong and R. Meier (2012). Barcoding and border biosecurity: identifying cyprinid fishes in the aquarium trade. PLoS One. 7(1): e28381.

Das, S., K. K. Misra and K. C. Ghose (1988). Scanning electron microscope studies on radular teeth of three gastropod molluscs (Prosobranchia: Mesogastropoda). Proc. Zool. Soc. Calcutta. 37: 71-79.

Deza, M. M and E. Deza (2013). Distances in Biology. In: Deza, M.M, Deza, E, editors. Encyclopedia of Distances. Heidelberg, Berlin: SpringerVerlag. 387-434.

Doherty, P. J., S. Planes and P. Mather (1995). Gene flow and larval duration in seven species of fish from the Great Barrier Reef. Ecology. 76: 2373-2391.

Duda, T. F and S. R. Palumbi (1999). Population structure of the black tiger prawn, Penaeus monodon, among western Indian Ocean and western Pacific populations. Mar. Biol. 134: 705-710.

Duffy, J. E. (1993). Genetic population structure in two tropical sponge-dwelling shrimps that differ in dispersal potential. Mar. Biol. 116: 459-470.

Feng, Y., Q. Li, L. Kong and X. Zheng (2011). DNA barcoding and phylogenetic analysis of Pectinidae (Mollusca: Bivalvia) based on mitochondrial COI and 16S rRNA genes. Mol. Biol. Rep. 38(1): 291-299.

Ferri, E., M. Barbuto, O. Bain, A. Galimberti, S. Uni, R. Gurrero, H. Ferte, C. Bandi, C. Martin and M. Casiraghi (2009). Integrated taxonomy: traditional approach and DNA barcoding for the identification of filarioid worms and related parasites (Nematoda). FRONT ZOOL. 6: 1-12.

Folmer, O., M. Black, W. Hoeh, R. Lutz and R. Vrijenhoek (1994). DNA primers for amplification of mitochondrial cytochrome c oxidase subunit I from diverse metazoan invertebrates. Mol Mar Biol Biotechnol. 3(5): 294-299.

Fontanilla, K. I., A. F. Torres, J. A. D. G. Cañasa, S. L. Yap and P. S. Ong (2014). State of animal DNA barcoding in the Philippines: A review of COI sequencing of the Philippine native fauna. Philippine Science Letters 4(1): 104-137.

Galarza, J. A., J. Carreras-Carbonell, E. Macpherson, M. Pascual, S. Roques, G. Turner and C. Rico (2009). The influence of oceanographic fronts and early-life-history traits on connectivity among littoral fish species. Proc Natl Acad Sci USA. 106: 1473-1478.

Gossner, M. M and A. Hausmann (2009). DNA barcoding enables the identification of caterpillars feeding on native and alien oak (Lepidoptera: Geometridae). Mitteilungen Muenchener Entomologischen Gesellschaft. 99: 135-140. 
Hebert, P. D. N., A. A. Cywinsk, S. L. Ball and J. R. Dewaard (2003b). Biological identifications through DNA barcodes. Proc R Soc Lond B. 270: 313-321.

Hebert, P.D.N., S. Ratnasingham and J. R. Dewaard (2003a). Barcoding animal life: cytochrome c oxidase subunit 1 divergences among closely related species. Proc R Soc Lond B. 270: 96-99.

Hellberg, M. E (1996). Dependence of gene flow on geographic distance in two solitary corals with different larval dispersal capabilities. Evolution. 50: 1167-1175.

Houbrick, R. S (1991). Systematic review and functional morphology of the mangrove snails Terebralia and Telescopium (Potamididae; Prosobranchia). Malacologia. 33: 289-338.

Hunt, A (1993). Effect of contrasting patterns of larval dispersal on the genetic connectedness of local populations of two intertidal starfish, Patieriella calcar and P. exigua. Marine Ecology Progress Series. 92: 179-186.

Kimura (1980). A simple method for estimating evolutionary rates of base substitutions through comparative studies of nucleotide sequences. J Mol Evol. 16: 111-120.

Koehn, R. K., R. I. E. Newell, and F. Immermann (1980). Maintenance of an aminopeptidase allele frequency cline by natural selection. Proceedings of the National Academy of Sciences of the USA. 77: 5385-5389.

Kress, W. J., C. Garcia-Robledo, M. Uriarte and D. L. Erickson (2015). DNA barcodes for ecology, evolution and conservation. Trends. Eco. Evol. 30: $25-35$.

Lasiak, T and A. H. Dye (1986). Behavioural Adaptation of the Mangrove Whelk, Telescopium telescopium (L.), to Life in a Semi-terrestrial Environment. J. Moll. Stud. 52: 174-179.

Lavery, S., C. Moritz and D. R. Fielder (1995). Changing patterns of population structure and gene flow at different spatial scales in Birgus latro (the coconut crab). Heredity. 74: 531-541.

Lavery, S., C. Moritz and D. R. Fielder (1996). IndoPacific population structure and evolutionary history of the coconut crab Birgus latro. Mol. Ecol. 5: 557-570.

Layton, K.K., A. L. Martel and P. D. Hebert (2014). Patterns of DNA barcode variation in Canadian marine molluscs. PloS one. 9(4): e95003.

McMillan, W. O and S. R. Palumbi (1995). Concordant evolutionary patterns among Indo-West Pacific butterflyfishes. Proceedings of the Royal Society of London, Series B, 260: 229-236.

Meziane, T and M. Tsuchiya (2002). Organic matter in a subtropical mangrove-estuary subjected to waste water discharge: origin and utilization by two macro zoobenthic species. J. Sea Res .47: 1-11.

Ngeve, M. N., T. V. D. Stocken, D. Menemenlis, N. Koedam and L. Triest (2016). Contrasting Effects of Historical Sea Level Rise and Contemporary Ocean Currents on Regional Gene Flow of Rhizophora racemosa in Eastern Atlantic Mangroves. Plosone. 11(3): e0150950.

Packer, L., J. Gibbs, C. Sheffield and R. Hanner (2009). DNA Barcoding and the mediocrity of morphology. Mol. Ecol. Resour. 9: 42-50.

Palumbi, S. R., G. Grabowsky, T. Duda, L. Geyer and N. Tachino (1997). Speciation and population genetic structure in tropical Pacific sea urchins. Evolution. 51: 1506-1517.

Powers, D.A., T. Lauerman, D. Crawford and L. DiMichele (1991). Genetic mechanisms for adapting to a changing environment. Annu. Rev. Genet. 25: 629-659.

Rakshit, S., D. K. Bhattacharyya and K. Misra (1997). Distribution of major lipids and fatty acids of the estuarine gastropod mollusc Telescopium telescopium. Folia Biologica. 45: 83-87.

Riginos, C and M. W. Nachman (2001). Blackwell Science, Ltd Population subdivision in marine environments: the contributions of biogeography, geographical distance and discontinuous habitat to genetic differentiation in a blennioid fish, Axoclinus nigricaudus. Mol. Ecol. 10:1439-1453.

Reid, D. G., P. Dyal, P. Lozouet, M. Glaubrecht and S. T. Williams (2008). Mudwhelks and mangroves: the evolutionary history of an ecological association (Gastropoda: Potamididae). Mol. Phylo. Evol. 47(2): 680-699.

Rocha-Olivares, A and R. D. Vetter (1999). Effects of oceanographic circulation on the gene flow, genetic structure, and phylogeography of the rosethorn rockfish (Sebastes helromaculatus). CAN J FISH AQUAT SCI. 56: 803-813.

Satheeshkumar, $P$ and L. Jagadeesan (2010). Phylogenetic Position and Genetic Diversity of Neridae-Polychaeta Based on Molecular Data from 16S rRNA Sequences. Middle East. J. Sci. Res.6(6): 550-555.

SatheeshKumar, P., P. K. Chinnamani, P. Paramasivam and U. Sundaresan (2020). DNA barcoding of horn snail Telescopium telescopium (Linnaeus C, 1758) using mt-COI gene sequences. Reg. Stud. Mar. Sci. 35: 101-109.

Satheeshkumar, P., and L. Jagadeesan (2010). Phylogenetic Position and Genetic Diversity of Neridae-Polychaeta Based on Molecular Data from 16S rRNA Sequences. Middle East. J. Sci. Res. 6(6): 550-555. 
Satheeshkumar, P., U. Manjusha and N. G. K. Pillai (2011). Conservation of mangrove forest covers in Kochi coast. Current. Sci. 101(10): 1400.

Satheeshkumar, P., U. Manjusha, N. G. K. Pillai and D. S. Kumar (2012). Puducherry mangroves under sewage pollution threat need conservation. Curr. Sci. 102(1): 13-14.

Schmidt, P.S and D. M. Rand (1999). Intertidal microhabitat and selection at MPI: interlocus contrasts in the northern acorn barnacle, Semibalanus balanoides. Evolution. 53:135-146.

Shanmugam, A and S. Rajagopal (2006). Molluscs. In: UNU-INWEH-UNESCO International Training Course on Biodiversity in Mangrove EcosystemCourse Manual, Kathiresan, K. and S.A. Khan (Eds.). Annamalai University, Parangipettai, India, 239-244. R.C.

Shulman, M. J and E. Bermingham (1995) Early life histories, ocean currents, and the population genetics of Caribbean reef fishes. Evolution. 49: 897-910.

Snidvongs, A and P. Sojisuporn (1999). Numerical simulation of the net current in the Gulf of Thailand under different monsoon regimes. Proceeding of the first technical seminar on marine fishery resources survey in the South
China Sea, Sea area I: Gulf of Thailand and East coast of peninsular Malaysia. 54-72.

Stepien, C. A (1999). Phylogeographical structure of the Dover sole Microstomus pacificus: the larval retention hypothesis and genetic divergence along the deep continental slope of the northeastern Pacific Ocean. Mol. Ecol. 8: 923939.

Sultana, R and J. Mustaquim (2003). Some physical parameters of the Sandspit backwaters, Karachi coast. Pakistan J. Su. Ind Res. 46(5): 333-343.

Waples, R. S (1987). A multispecies approach to the analysis of gene flow in marine shore fishes. Evolution. 41: 385-400.

Werner, F. E., R. K. Cowen and C. B. Paris (2007). Coupled biological and physical models. Oceanography. 20: 54-69.

Willan, R. C (2013). A key to the potamidid snails, longbums, mud creepers and tree creepers of northern Australia. North Territ Nat. 24: 68-80.

Yap, C. K., A. Noorhaidah, A. Azlan, A. N. Azwady, A. Ismail and A. R. Ismail (2009). Telescopium telescopium as potential biomonitors of $\mathrm{Cu}, \mathrm{Zn}$, and $\mathrm{Pb}$ for the tropical intertidal area. Eco toxi. Enviro. Safety. 72(2): 496-506. 